\title{
PENGARUH LAYANAN SETORAN ONLINE USID (UGT SYSTEM INTEGRATOR DEVELOPMENT) GATEWAY TERHADAP KEPUASAN DAN LOYALITAS NASABAH DI BMT UGT SIDOGIRI CABANG KLAMPIS KABUPATEN BANGKALAN
}

\author{
Oleh: \\ Fuad Malik Romadhon ${ }^{1} \&$ Muhaimin ${ }^{2}$ \\ Email: fuadsnc@gmail.com \& muhaimin_mafandi@yahoo.co.id
}

\begin{abstract}
The online deposit service implemented by BMT UGT Sidogiri Klampis Bangkalan Branch is an effort or strategic steps carried out by BMT UGT Sidogiri to attract customers and provide satisfaction and create customer loyalty. The purpose of this study was to determine the effect of implementing online deposit services on customer satisfaction and loyalty. The design of this study is quantitative research with data collection methods through questionnaire surveys or questionnaires that have been tested for validity and reliability. The sampling technique uses simple random sampling method with a total sample of 88 people who use online deposit services. Analysis using simple linear regression, the data is processed using the SPSS 19.0 program. The results of the study show that: (1) the description of quality online deposit services with a percentage of $87 \%$. (2) An overview of customer satisfaction with online deposit services is quite good with a percentage of $84 \%$ (3) An overview of customer loyalty to online deposit services by $85 \%$ (4) There is a significant influence between online deposit services on customer satisfaction (5) There is a significant influence between online deposit services to customer loyalty. So based on these results, this deposit service should continue to be run and developed in order to continue to provide satisfaction and create customer loyalty that has a positive impact on the existence and progress of the company.
\end{abstract}

Key words: service quality, deposit, online, satisfaction, loyalty

\section{Pendahuluan}

Perkembangan teknologi informasi yang sangat cepat, direspon oleh perusahaan atau lembaga keuangan untuk menciptakan inovasi-inovasi

\footnotetext{
${ }^{1}$ Alumni S-1 Prodi Ekonomi Syariah STAI Syaichona Moh. Cholil Bangkalan

${ }^{2}$ Dosen STAI Syaichona Moh. Cholil Bangkalan
} 
yang dapat memberikan dampak positif bagi nasabah dan perusahaan. Dalam perusahaan jasa, kualitas pelayanan merupakan sesuatu yang sangat penting. Berbagai usaha terus dilakukan demi mewujudkan pelayanan yang berkualitas. Dengan memanfaatkan teknologi yang ada, perusahaan terus mengembangkan sesuatu yang dapat memudahkan dalam mewujudkan target-target yang ingin di capai oleh perusahaan.

Kepuasan dan loyalitas nasabah merupakan salah satu target utama setiap perusahaan dalam memasarkan produk atau jasa yang dihasilkan. Dengan kepuasan akan tercipta loyalitas konsumen untuk setia menggunakan produk atau jasa tersebut. Kepuasan konsumen akan tercipta ketika terjadi kecocokan antara prediksi dan kenyataan yang diperoleh saat mengkonsumsi barang atau jasa tertentu. Loyalitas yang muncul sebagai akibat timbal balik konsumen terhadap kepuasan yang diperoleh dan loyalitas tersebut sangat dibutuhkan perusahaan untuk keberlanjutan usahanya di mata pasar.

Kepuasan pelanggan (nasabah) ditentukan oleh kualitas produk dan kualitas layanan yang sesuai dan dikehendaki oleh nasabah sehingga jaminan kualitas menjadi kualitas utama bagi suatu perusahaan. ${ }^{3}$ Kepuasan pelanggan terhadap layanan terdapat dua hal pokok yang saling berkaitan erat yaitu harapan pelanggan terhadap kualitas layanan (expected quality) dan persepsi pelanggan terhadap kualitas layanan (perceived quality). ${ }^{4}$ Pelanggan akan selalu menilai suatu layanan yang diterima dibandingkan dengan apa yang diharapkan atau diinginkannya. Penilaian pelanggan inilah yang menjadi input yang sangat penting bagi suatu perusahaan, untuk meningkatkan kualitas dari produk atau jasa yang dihasilkan.

Dalam industri perbankan, kualitas produk yang diukur adalah kualitas layanan untuk mewujudkan kepuasan nasabah. Seperti pembahasan di atas kepuasan nasabah sangat berpengaruh terhadap loyalitas nasabah. Sehingga hal tersebut harus terus diupayakan untuk membentuk loyalitas nasabah. Apabila loyalitas nasabah tidak terwujud

\footnotetext{
${ }^{3}$ Riswandhi Ismail. Pengaruh Kualitas Layanan, Kualitas Produk Dan Kepuasan Nasabah Sebagai Prediktor Dalam Meningkatkan Loyalitas Nasabah, Jurnal Organisasi dan Manajemen, Volume 10, Nomor 2, September 2014, pp 179-196

${ }^{4}$ Philip Kotler, Kevin Lane Keller. Manajemen Pemasaran, Edisi Ketiga Belas. Jakarta: Erlangga. 2009, hlm 139.
} 
maka nasabah akan berpindah kepada lembaga keuangan lain yang hal tersebut akan mengurangi profit perusahaan dan mengurangi daya saing serta mengancam eksistensi perusahaan seperti yang diungkapkan oleh Griffin" "Practice the 80/20 rule, artinya 80\% pendapatan perusahaan bisa datang dari 20\% konsumen. Dalam dunia bisnis ada sebanyak 20\% konsumen, tapi memberikan penghasilan sebesar $80 \%$ ke perusahaan. Konsumen tersebut, tentunya adalah konsumen yang loyal.

Peningkatan kualitas pelayanan dapat dilakukan dengan meningkatkan kualitas infrastruktur dan sumber daya insani yang ada dalam perusahaan mengikuti alur perkembangan era globalisasi, yakni dalam lingkup teknologi. Pelayanan diciptakan dan didesain harus sebisa mungkin memberikan rasa menyenangkan kepada nasabah disertai kemudahan-kemudahan, ketepatan dan memenuhi segala kebutuhan nasabah. Karena untuk menciptakan nasabah yang puas dan loyal dalam pembelian tidaklah mudah, oleh sebab itu perusahaan harus mampu memberikan inovasi-inovasi terbaru terhadap perusahaannya seiring dengan perkembangan zaman terkait dengan perkembangan teknologi.

BMT UGT Sidogiri mendirikan sebuah anak perusahaan yang bergerak di bidang teknologi yaitu PT. UGT System Integrator Development Gateway. Pada Tahun 2015, meluncurkan sebuah aplikasi yang diberi nama U-Mobile USID Gateway, aplikasi tersebut di-install dan dioperasikan dengan menggunkaan smartphone berbasis sistem operasi android. Aplikasi U-Mobile USID Gateway merupakan pengembangan dari aplikasi yang sebelumnya dipakai oleh BMT UGT Sidogiri yaitu Negakom Mobile. Negakom Mobile merupakan aplikasi pihak ketiga yang dikelola oleh PT Negakom Indonesia yang pernah digunakan oleh BMT UGT Sidogiri pada kurun waktu 3 tahun sebelumnya yaitu sejak tahun 2012 sampai 2015.

Keunggulan Usid Mobile dibandingkan Negakom Mobile adalah Usid Mobile memiliki fitur yang lebih lengkap, aplikasi ini memuat memuat berbagai data nomor rekening nasabah, alamat nasabah, beserta catatan setoran tabungan sebelumnya dan saldo nasabah terbaru yang sebelumnya tidak terdapat pada aplikasi negakom. Aplikasi USID Gateway juga dapat

${ }^{5}$ Griffin. Customer Loyalty, How to Earn it, How to Keep it. New York. 2002, hlm. 
memuat data angsuran nasabah yang terintegrasi langsung dengan database yang berada di server pusat. Aplikasi ini juga dapat menghasilkan print out yang berupa slip bukti transaksi melalui thermall printer yang selalu dibawa oleh account officer (AO).

Penelitian sebelumnya yang dilakukan oleh Nor Liza yang berjudul Penggunaan Sistem Setoran Online UGT Sidogiri Gateway (Usid Gateway) dan Sistem Setoran Offline: Studi Komparasi Terhadap Kepuasan Nasabah Pada Tabungan Umum Syariah Di KJKS BMTUGT Sidogiri Capem Mojo Surabaya membahas tentang perbandingan sistem online dengan sistem manual. Akan tetapi dalam penelitian tersebut menurut peneliti masih belum maksimal dalam mengukur tingkat kepuasan nasabah BMT UGT Sidogiri yang menggunakan layanan tersebut. Karena titik fokusnya lebih kepada perbandingan.

Hal inilah yang menjadi salah satu dasar peneliti tertarik untuk membahas lebih dalam aplikasi tersebut dan implementasinya. Peneliti juga ingin mengetahui lebih dalam apakah ada pengaruh sistem layanan setoran online Usid Gateway terhadap kepuasan dan loyalitas nasabah tabungan syariah di KJKS BMT UGT Sidogiri Cabang Klampis Kabupaten Bangkalan.

\section{Metode Penelitian}

Rancangan penelitian ini adalah empiris kuantitatif yaitu pendekatan yang memungkinkan pencatatan hasil penelitian dalam bentuk angka dan untuk meneliti populasi atau sampel tertentu, pengumpulan data menggunakan instrumen penelitian, analisis data bersifat statistik, dengan tujuan untuk menguji hipotesis yang telah ditetapkan. ${ }^{6}$ Penelitian ini, digunakan pendekatan kuantitatif dengan desain survei. Fokus utama penelitian adalah menganalisis pengaruh kualitas layanan setoran online (Usid Gateway) terhadap kepuasaan dan loyalitas nasabah pada investasi tabungan di BMT UGT Sidogiri Cabang Klampis Kabupaten Bangkalan.

Dalam penelitian ini populasi yang digunakan adalah nasabah di BMT UGT Sidogiri Cabang Klampis Kabupaten Bangkalan pada tahun

\footnotetext{
${ }^{6}$ Sugiyono. Metode Penelitian Kualitatif Kuantitatif $R \& D$. Bandung: Alfabeta.
} 2011, hlm 7 
2018 yang menggunakan layanan sistem setoran layanan online yang berjumlah 700 nasabah. Untuk menentukan berapa sampel yang dibutuhkan, maka digunakan rumus Slovin. ${ }^{7}$

Dalam penelitian ini variabel independennya adalah sistem setoran online Usid Gateway $(\mathrm{X})$, sedangkan variabel dependennya adalah kepuasan nasabah (Y1) dan loyalitas nasabah (Y2). Layanan online yang didasari dari konsep yang dikemukakan oleh Zeithaml and Parasuraman yaitu8: efficiency (efisiensi), fulfillment (pemenuhan kebutuhan), system availability (ketersediaan system) dan privacy (privasi). Sedangkan kepuasan nasabah dalam konseptual penelitian ini didasari oleh teori Fandy Tjiptono ${ }^{9}$ yaitu: (1) penyediaan layanan yang baik; (2) karyawan cepat dalam menyelesaikan pekerjaan; (3) karyawan mampu mengetahui keinginan dan mendiagnosis hal yang harus dilakukan dengan cepat; (4) karyawan memberikan perhatian individu dengan baik kepada keluhan konsumen. Loyalitas nasabah dalam konseptual penelitian ini didasari oleh teori Fandy Tjiptono ${ }^{10}$ yaitu: (1) pembelian ulang; (2) kebiasaan mengkonsumsi merek (3) rasa suka yang besar pada merek (4) ketetapan pada merek (5) keyakinan bahwa merek tertentu adalah yang terbaik (6) perekomendasian merek kepada orang lain

Metode pengumpulan data digunakan metode kuesioner untuk metode utama. Sebagai data pendukung penelitian, digunakan metode observasi, dokumentasi. Instrumen penelitian dilakukan uji validitas dan reliabilitas. Analisis datanya digunakan regresi linear sederhana dengan bantuan komputer menggunakan program SPSS (Statistical Packages for Social Science) versi 19.00 for Windows10.

${ }^{7}$ Ety Rochayety dkk. "Metodologi penelitian bisnis dan aplikasi SPSS”. Jakarta: Mitra Wacana Media. 2009, hlm 36.

${ }^{8}$ Parasuraman, A, Valarie A. Zeithaml, Arvind Malhotra. 2005. E-S-Qual (A Multiple-Item Scale for Assessing Electronic Service Quality). Journal of Service Research

${ }^{9}$ Fandy Tjiptono. "Manajemen Jasa". Yogyakarta: Andi Offset Fornel, Edisi Keempat. 2007, hlm 166.

${ }^{10}$ Ibid. hlm. 180. 


\section{Hasil Penelitian dan Pembahasan}

Layanan Setoran Online Usid Gateway

Secara keseluruhan hasil rekapitulasi data kuesioner nasabah dalam prespektif layanan setoran online usid gateway didapatkan hasil data sebagai berikut.

Tabel 1

Rekapitulasi Skor Penilaian Responden Aspek Layanan Online

\begin{tabular}{|c|c|c|c|c|c|}
\hline No. & Nilai & $\begin{array}{c}\text { Layanan } \\
\text { Online }\end{array}$ & Frekuensi & Presentase & $\begin{array}{c}\text { Jumlah Skor } \\
\text { Angket }\end{array}$ \\
\hline 1. & $90-100$ & Sangat Baik & 77 & $87,5 \%$ & 7330 \\
\hline 2. & $80-89$ & Baik & 9 & $10,3 \%$ & 783 \\
\hline 3. & $70-79$ & Cukup & 1 & $1,1 \%$ & 76 \\
\hline 4. & $60-69$ & Kurang & 1 & $1,1 \%$ & 68 \\
\hline 5. & $<60$ & Sangat Kurang & 0 & $0 \%$ & 0 \\
\hline \multicolumn{7}{|c|}{ Total rata-rata (Jumlah Skor Angket: Jumlah Responden $\times$ ) $=93,8 \%$} \\
\hline
\end{tabular}

Berdasarkan rekapitulasi data pada tabel 1 di atas menunjukkan bahwa secara keseluruhan mengenai prespektif layanan online 77 responden $(87,5 \%)$ berpendapat bahwa layanan setoran online yang disediakan oleh BMT UGT Sidogiri Cabang Klampis Kabupaten Bangkalan sangat baik, 9 responden $(10,3 \%)$ menyatakan baik, 1 responden $(1,1 \%)$ bersikap netral serta 1 responden $(1,1 \%)$ menyatakan kurang baik. Total skor angket yang didapatkan dalam penelitian ini adalah 8257. Total skor tersebut dibagi dengan jumlah responden yaitu sebanyak 88 responden sehingga menghasilkan angka 93,8 atau bila dipresentasekan yaitu menghasilkan presentase sebesar 93,8 \%.

Berdasarkan hasil penelitian layanan setoran online menunjukkan bahwa layanan ini cukup diminati oleh nasabah. 93,8 persen nasabah merasa puas akan layanan tersebut. Proses transaksi dengan menggunakan sistem setoran online sangat memudahkan nasabah maupun AO (Account Officer). Sistem setoran online sendiri merupakan sistem setoran dengan menggunakan sebuah aplikasi yang sudah dimiliki oleh setiap AO BMT UGT Sidogiri Cabang Klampis Kabupaten Bangkalan yang termuat di dalam smartphone AO. Aplikasi yang disebut dengan Usid (UGT System Integrator Development) Gateway tersebut memuat berbagai data nomor 
induk beserta catatan setoran tabungan dan saldo nasabah. AO menerima setoran tabungan dari nasabah dan langsung diinput melalui aplikasi Usid Gateway.

Nasabah bisa langsung mengecek saldo tabungannya saat melakukan setoran tabungan dari struk yang keluar setelah penginputan data setoran dari sebuah mobile printer yang selalu dibawa oleh $\mathrm{AO}$ pada saat pengambilan setoran tabungan. Data setoran yang telah diinput AO langsung masuk ke dalam catatan data setoran dan saldo nasabah yang ada di dalam komputer. Kemudahan itu tidak hanya dirasakan oleh nasabah tapi juga dirasakan oleh AO. AO sendiri tidak harus mencatat atau menginput lagi data setoran nasabah di komputer. Kecepatan dan efisiensi waktu yang diperoleh ketika menggunakan sistem online ini sangat mempengaruhi kualitas kinerja $\mathrm{AO}$.

Layanan setoran online telah memenuhi segala aspek kualitas layanan online yang dibutuhkan oleh nasabah. Layanan dan aplikasi yang digunakan sudah teruji kualitas dan kredibilitasnya dan layanan yang telah diberikan telah memenuhi harapan nasabah dari segala aspek yang telah di paparkan. Harapan pelanggan mempunyai peranan penting dalam menentukan kualitas produk (barang dan jasa) dan kepuasan pelanggan karena pada dasarnya terdapat hubungan yang erat antara penentuan kualitas dan kepuasan pelanggan. ${ }^{11}$

\section{Data Kepuasan Nasabah}

Dari perspektif kepuasan nasabah dalam aspek penyediaan layanan yang baik yang meliputi keramahan karyawan dan nasabah merasa aman dan nyaman dalam melakukan transaksi setoran, secara umum menurut penilaian responden diperoleh sebagai berikut.

${ }^{11}$ Irawan, H. 10 Prinsip Kepuasan Pelanggan. Jakarta: Gramedia Pustaka Utama. 2010. hlm .125 
Tabel 2

Rekapitulasi Skor Penilaian Responden Prespektif Kepuasan

\begin{tabular}{|c|c|c|c|c|c|}
\hline No. & Nilai & Kepuasan & Frekuensi & Presentase & $\begin{array}{c}\text { Jumlah Skor } \\
\text { Angket }\end{array}$ \\
\hline 1. & $90-100$ & Sangat Puas & 62 & $70,5 \%$ & 5824 \\
\hline 2. & $80-89$ & Puas & 23 & $26,2 \%$ & 2027 \\
\hline 3. & $70-79$ & Cukup & 1 & $1,1 \%$ & 75 \\
\hline 4 & $61-70$ & Kurang & 1 & $1,1 \%$ & 69 \\
\hline 5. & $<60$ & Sangat Kurang & 1 & $1,1 \%$ & 58 \\
\hline \multicolumn{7}{|c|}{ Total } & 88 & $100 \%$ & 8053 \\
\hline \multicolumn{7}{|c|}{ Rata-rata (Jumlah Skor Angket: Jumlah Responden $\times$ ) $=91,5 \%$} \\
\hline
\end{tabular}

Berdasarkan rekapitulasi data pada tabel 2 di atas menunjukkan bahwa secara keseluruhan perspektif kepuasan nasabah 62 responden (70,5\%) berpendapat bahwa layanan setoran online yang disediakan oleh BMT UGT Sidogiri Cabang Klampis Kabupaten Bangkalan sangat puas, 23 responden $(26,2 \%)$ menyatakan puas, 1 responden $(1,1 \%)$ bersikap netral, serta 1 responden $(1,1 \%)$ menyatakan kurang puas dan 1 responden $(1,1 \%)$ menyatakan sangat tidak puas. Total skor angket yang didapatkan dalam penelitian ini adalah 8053. Total skor tersebut dibagi dengan jumlah responden yaitu sebanyak 88 responden sehingga menghasilkan angka 91,5 atau bila dipresentasekan yaitu menghasilkan presentase sebesar 91,5 \% .

Berdasarkan hasil penelitian kepuasan terhadap layanan setoran online yang diberikan menunjukkan bahwa layanan ini cukup memberikan kepuasan kepada nasabah. 91,5 \% nasabah merasa puas akan layanan tersebut, secara umum kepuasan nasabah di BMT UGT Sidogiri Cabang Klampis Kabupaten Bangkalan secara umum tergolong baik. Dalam penelitian ini program atau layanan yang diberikan telah memenuhi harapan dan kebutuhan nasabah. Sehingga secara keseluruhan kepuasan nasabah dapat terpenuhi. Hal ini telah sesuai dengan apa yang dikemukakan oleh Fandy Tjiptono yang mengungkapkan kepuasan pelanggan adalah tingkat perasaan seseorang setelah membandingkan kinerja (hasil) yang dirasakan dibandingkan dengan harapan. ${ }^{12}$ Juga seperti apa yang dikemukakan oleh Kotler yang menyatakan kepuasaan

\footnotetext{
${ }^{12}$ Fandy Tjiptono, Anstasia. Total Quality Service. Yogyakarta: Andi Ofsset 2001. hlm. 152
} 
pelanggan adalah tingkat perasaan setelah membandingkan kinerja (atau hasil) yang dirasakan dibandingkan dengan harapan. ${ }^{13}$ Jadi tingkat kepuasaan adalah fungsi dari perbedaan antara kinerja yang dirasakan dengan harapan. Pelanggan dapat mengalami salah satu tingkat kepuasaan yang umum.

Kepuasan ini adalah kepuasan atas layanan online yang diberikan oleh BMT UGT Sidogiri. Efisisensi, pemenuhan kebutuhan, ketersediaan sistem dan privasi nasabah telah terpenuhi oleh layanan ini. Kepuasan nasabah dengan penyediaan layanan yang baik oleh BMT UGT Sidogiri Cabang Klampis dirasa telah dapat memuaskan nasabah dalam hal melakukan transaksi setoran tabungan. Dengan keramahan dan kenyamanan yang diberikan oleh AO membuat nasabah senang menabung di BMT UGT Sidogiri Cabang Klampis mengunakan layanan setoran tabungan online tersebut.

\section{Data Loyalitas Nasabah}

Perspektif loyalitas nasabah dalam aspek perekomendasian terhadap orang lain yang meliputi nasabah akan merekomendasikan kepada orang lain, menceritakan layanan yang diberikan secara positif secara umum menurut penilaian responden diperoleh sebagai berikut.

Tabel 3

Rekapitulasi Skor Penilaian Aspek Loyalitas

\begin{tabular}{|c|c|c|c|c|c|}
\hline No. & Nilai & Loyalitas & Frekuensi & Presentase & $\begin{array}{c}\text { Total Skor } \\
\text { Angket }\end{array}$ \\
\hline 1. & $91-100$ & Sangat Loyal & 69 & $78,5 \%$ & 6625 \\
\hline 2. & $81-90$ & Loyal & 14 & $15,9 \%$ & 1355 \\
\hline 3. & $71-80$ & Cukup & 4 & $4,5 \%$ & 149 \\
\hline 4. & $61-70$ & Kurang Loyal & 1 & $1,1 \%$ & 64 \\
\hline 5. & $<60$ & Sangat Tidak Loyal & 0 & $0 \%$ & 0 \\
\hline \multicolumn{2}{|r|}{ Total } & 88 & $100 \%$ & 8193 \\
\hline
\end{tabular}

${ }^{13}$ Philip Kotler, Kevin Lane Keller. Manajemen Pemasaran. Edisi Ketiga Belas. Jakarta: Erlangga. 2009, hlm 54. 
Berdasarkan rekapitulasi data pada tabel 3 di atas menunjukkan bahwa secara keseluruhan mengenai prespektif loyalitas 69 responden $(78,5 \%)$ berpendapat bahwa layanan setoran online yang disediakan oleh BMT UGT Sidogiri Cabang Klampis Kabupaten Bangkalan sangat loyal, 14 responden $(15,9 \%)$ menyatakan loyal, 4 responden $(4,5 \%)$ bersikap netral, serta 1 responden $(1,1 \%)$ menyatakan kurang loyal. Total skor angket yang didapatkan dalam penelitian ini adalah 8193. Total skor tersebut dibagi dengan jumlah responden yaitu sebanyak 88 responden sehingga menghasilkan angka 93,1 atau bila dipresentasekan yaitu menghasilkan presentase sebesar 93,1\%.

Berdasarkan hasil penelitian dan hasil rekapitulasi angket responden dalam prespektif loyalitas dari berbagai aspek yang ada, loyalitas nasabah kepada BMT UGT Sidogiri Cabang Klampis Kabupaten Bangkalan dengan adanya layanan setoran online yang disediakan menunjukkan bahwa, layanan ini mempengaruhi loyalitas nasabah yaitu sebesar 93,1 \%. Loyalitas nasabah merupakan hal yang harus tetap dijaga oleh setiap lembaga keuangan.

Aspek perekomendasian terhadap orang lain nasabah BMT UGT Sidogiri cenderung bersedia merekomendasikan BMT UGT Sidogiri kepada keluarga, teman, dan orang orang di sekitar mereka. Mereka bersedia untuk bercerita secara positif kepada orang lain tentang layanan yang diberikan oleh BMT UGT Sidogiri. Seperti yang dilakukan oleh para pedagang di pasar tradisional klampis mereka mengajak para pedagang yang lain untuk ikut menabung.

Pedagang pasar tradisional sudah terbiasa menabung di BMT UGT Sidogiri, hal tersebut terlihat dari kebiasaan mereka menyisipkan sejumlah uang di tabungan mereka setiap hari untuk disetorkan ketika AO datang. Sehingga ketika AO tidak datang atau tidak masuk bekerja, uang setoran tersebut diberikan pada hari berikutnya. Kebiasaan menabung tersebut bukan hanya dilakukan oleh nasabah kalangan pedagang besar saja. Semua nasabah bisa menggunakan layanan ini karena layanan ini tidak menetapkan batas minimal setoran, berbeda halnya dengan setoran offline yang dilakukan ke kantor cabang, yang menetapkan setoran minimal sebesar 5000 Rupiah. 
Loyalitas nasabah BMT UGT Sidogiri Cabang Klampis Bangkalan dalam aspek keyakinan bahwa merek tertentu adalah yang terbaik, terlihat dari banyaknya nasabah yang beranggapan bahwa BMT UGT Sidogiri adalah pilihan utama mereka untuk menabung. Banyak di antara nasabah yang hanya memiliki satu rekening tabungan, yaitu mereka hanya menabung di BMT UGT Sidogiri padahal banyak lembaga keuangan lain yang berada di sekitarnya. Hanya ada beberapa nasabah yang memiliki rekening di lembaga keuangan lain. Menurut nasabah yang mempunyai rekening lain di bank mereka mengaku bahwa rekening tersebut hanya digunakan sebagai media transfer uang dari keluarga mereka yang berada di perantauan.

\section{Pengaruh Layanan Setoran Online Usid Gateway Terhadap Kepuasan Nasabah}

Untuk mengetahui seberapa besar pengaruh layanan setoran online Usid Gateway dengan kepuasan nasabah BMT UGT Sidogiri Cabang Klampis Bangkalan digunakan analisis regresi linear sederhana dengan bantuan IBM SPSS versi 19.00 dengan diperoleh data sebagai berikut.

Tabel 4

Nilai Koefisien Korelasi dan Determinasi Usid Terhadap Kepuasan Nasabah

\begin{tabular}{|l|r|r|r|r|r|}
\hline Model & \multicolumn{1}{|c|}{$\mathrm{R}$} & R Square & \multicolumn{1}{|c|}{$\begin{array}{c}\text { Adjusted R } \\
\text { Square }\end{array}$} & \multicolumn{1}{c|}{$\begin{array}{c}\text { Std. Error of the } \\
\text { Estimate }\end{array}$} & Durbin-Watson \\
\hline 1 & $.841^{\mathrm{a}}$ & .707 & .704 & 3.975 & .811 \\
\hline
\end{tabular}
a. Predictors: (Constant), Usid
b. Dependent Variable: Kepuasan

Berdasarkan analisis data diperoleh nilai koefisien korelasi $\mathrm{R}=$ 0,841 . Hal ini menunjukkan pengaruh yang kuat antara variabel layanan setoran online terhadap kepuasaan nasabah. Sedangan koefisien determinasi R Square adalah 0,707 yang berarti bahwa variabel layanan setoran online dapat menggambarkan terhadap variabel kepuasan nasabah sebesar 70,7 \%, sisanya dipengaruhi oleh faktor lainnya. 
Tabel 5

Hasil Koefisien Regresi Usid Terhadap Kepuasan Nasabah

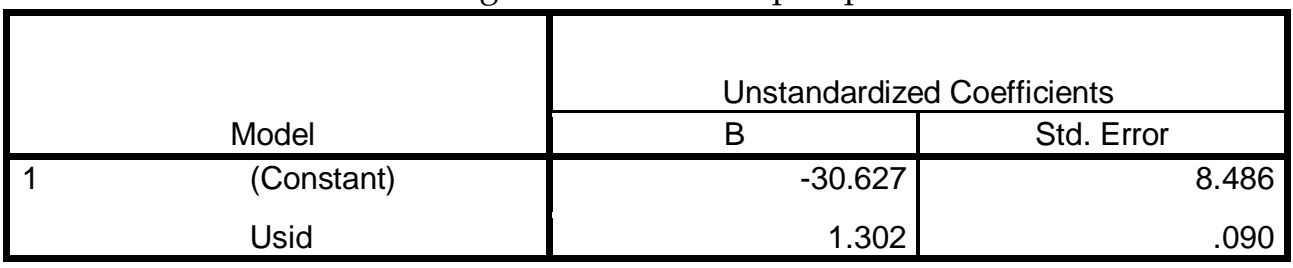

\begin{tabular}{|c|c|c|c|c|c|}
\hline \multirow[b]{2}{*}{ Model } & $\begin{array}{c}\text { Standardized } \\
\text { Coefficients }\end{array}$ & \multirow[b]{2}{*}{$\mathrm{T}$} & \multirow[b]{2}{*}{ Sig. } & \multicolumn{2}{|c|}{ 95.0\% Confidence Interval for B } \\
\hline & Beta & & & Lower Bound & $\begin{array}{l}\text { Upper } \\
\text { Bound }\end{array}$ \\
\hline $1 \quad$ (Constant) & & -3.609 & .001 & -47.497 & -13.757 \\
\hline Usid & .841 & 14.411 & .000 & 1.122 & 1.481 \\
\hline
\end{tabular}

Berdasarkan analisis data diperoleh nilai koefisien korelasi $\mathrm{R}=0,841$. Hal ini menunjukkan pengaruh yang kuat layanan setoran online terhadap kepuasaan nasabah. Hasil $p$ value diperoleh 0,000 $<0,05$ sehingga menerima hipotesis kerja dan menolak hipotesis nihil. Dengan demikian ada pengaruh yang signifikan antara layanan setoran online dengan kepuasan nasabah pada BMT UGT Sidogiri Cabang KlampisKabupaten Bangkalan.

\section{Pengaruh Layanan Setoran Online Usid Gateway Terhadap Loyalitas Nasabah}

Untuk mengetahui seberapa besar pengaruh Layanan Setoran Online Usid Gateway dengan loyalitas nasabah BMT UGT Sidogiri Cabang KlampisKabupaten Bangkalan digunakan analisis regresi linear sederhana dengan bantuan IBM SPSS versi 19.00 dengan diperoleh data sebagai berikut. 
Tabel 6

Nilai Koefisien Korelasi dan Determinasi Usid Terhadap Loyalitas

\begin{tabular}{|l|r|r|r|r|}
\hline Model & $\mathrm{R}$ & $\mathrm{R}$ Square & Adjusted R Square & $\begin{array}{c}\text { Std. Error of the } \\
\text { Estimate }\end{array}$ \\
\hline 1 & $.849^{\mathrm{a}}$ & .721 & .718 & 3.501 \\
\hline
\end{tabular}

a. Predictors: (Constant), Usid

b. Dependent Variable: Loyalitas

Berdasarkan analisis data diperoleh nilai koefisien korelasi $\mathrm{R}=0,849$ Hal ini menunjukkan pengaruh yang kuat antara variabel layanan setoran online terhadap loyalitas nasabah. Sedangan koefisien determinasi R Square adalah 0,721 yang berarti bahwa variabel layanan setoran online dapat menggambarkan terhadap variabel loyalitas nasabah sebesar 72,1 \%, sisanya dipengaruhi oleh faktor lainnya.

Tabel 7

Hasil Koefisien Regresi Usid Terhadap Loyalitas

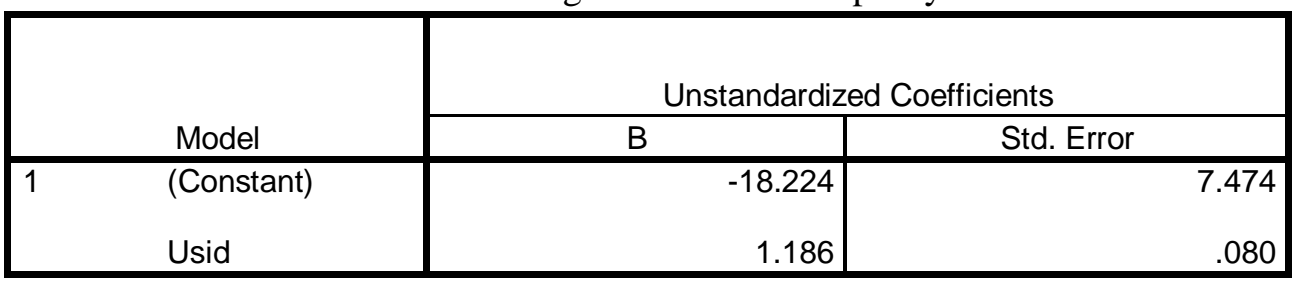

\begin{tabular}{|l|r|r|r|r|r|}
\hline \multirow{2}{*}{ Model } & \multicolumn{2}{|c|}{$\begin{array}{c}\text { Standardized } \\
\text { Coefficients }\end{array}$} & & & \multicolumn{2}{|c|}{$95.0 \%$ Confidence Interval for B } \\
\cline { 2 - 4 } \cline { 5 - 6 } & Beta & \multicolumn{1}{c|}{$\mathrm{T}$} & \multicolumn{1}{c|}{ Sig. } & Lower Bound & Upper Bound \\
\hline $1 \quad$ (Constant) & & -2.438 & .017 & -33.082 & -3.365 \\
Usid & .849 & 14.913 & .000 & 1.028 & 1.345 \\
\hline
\end{tabular}

Berdasarkan analisis data diperoleh nilai koefisien korelasi $\mathrm{R}=0,849$. Hal ini menunjukkan pengaruh yang kuat layanan setoran online terhadap loyalitas nasabah. Hasil $p$ value diperoleh 0,000 $<0,05$ sehingga menerima hipotesis kerja dan menolak hipotesis nihil. Dengan demikian ada pengaruh yang signifikan antara layanan setoran online terhadap loyalitas nasabah pada BMT UGT Sidogiri Cabang KlampisKabupaten Bangkalan. 


\section{Pengaruh Layanan Setoran Online Terhadap Kepuasan Nasabah}

Berdasarkan analisis data yang diperoleh koefisien korelasi $R=0,841$. Hal ini menunjukkan pengaruh yang kuat antara variabel layanan setoran online terhadap kepuasan nasabah. Sedangkan koefisien determinasi $\mathrm{R}$ Square adalah sebesar 0,707 yang berarti bahwa variabel setoran online dapat menggambarkan terhadap variabel kepuasan nasabah sebesar 70,7 $\%$. Sedangkan $29,3 \%$ kepuasan nasabah dipengaruh faktor lain.

Hasil $p$ value diperoleh 0,000 < 0,005 sehingga menerima hipotesis kerja dan menolak hipotesis nihil. Dengan demikian ada pengaruh yang signifikan antara layanan setoran online terhadap kepuasan nasabah pada BMT UGT Sidogiri Cabang Klampis Bangkalan.

Berdasarkan hasil analisis data tersebut BMT UGT Sidogiri Cabang Klampis harus sadar akan pentingnya layanan setoran online ini bagi nasabah. Layanan ini harus dapat dipertahankan, diperbaharui dan dikembangkan agar nasabah semakin termotivasi untuk menabung sehingga tingkat kepuasan bisa tetap terjaga bahkan terus meningkat. Dengan kemunculan teknologi digital seperti internet, pelanggan yang semakin pandai mengikuti alur perkembangannya pun mengaharapkan perusahaan bisa melakukan lebih banyak hal dari hanya sekedar hubungan langsung dengan pelanggan, memuaskan pelanggan dan bahkan lebih dari sekedar menyenangkan pelanggan. Pelanggan selalu memiliki ekspektasi (harapan) yang tinggi dalam mengkonsumsi suatu produk.

Terdapat dua faktor utama yang memengaruhi kualitas jasa, yaitu expected service dan perceived service. Apabila jasa yang diterima atau dirasakan (perceived service) sesuai dengan yang diharapkan maka kualitas jasa yang dipersepsikan baik dan memuaskan. Jika pelayanan yang diterima melampaui harapan konsumen, maka kualitas pelayanan dipersepsikan sebagai kualitas pelayanan yang ideal.14

Strategi pelayanan yang baik yang mampu menciptakan kepuasan nasabah dapat dijadikan sarana untuk meningkatkan keunggulan bersaing. Hal tersebut ditujukan dalam penelitian Zeithaml dimana dalam penelitian tersebut peneliti menunjukkan bahwa strategi

${ }^{14}$ Parasuraman, A, Valarie A. Zeithaml, Arvind Malhotra. 2005. E-S-Qual (A Multiple-Item Scale for Assessing Electronic Service Quality). Journal of Service Research 
pelayanan mempunyai dampak yang sangat kuat terhadap perilaku nasabah seperti loyalitas terhadap produk sebagai bagian dari rasa puas serta adanya kemauan untuk membayar lebih dan keengganan untuk berpindah ke produk lain. Dengan demikian, berarti strategi pelayanan membuat perbankan pada kinerja yang lebih baik. ${ }^{15}$

Pengembangan sistem setoran online yang dilakukan BMT UGT Sidogiri Cabang Klampis Bangkalan dapat memenuhi ekspektasi nasabah sehingga memberikan dampak yang positif bagi perusahaan. Layanan setoran online BMT UGT Sidogiri merupakan layanan yang belum atau tidak banyak dimiliki oleh lembaga keuangan lain. Akan tetapi hal tersebut tidak menutup kemungkinan perusahaan jasa lain di sekitarnya turut mengaplikasikan layanan tersebut. Sehingga hal tersebut dapat menjadi ancaman bagi BMT UGT Sidogiri dalam menjaga loyalitas nasabahnya.

Kepuasan yang telah terbangun dari adanya layanan setoran online ini merupakan suatu pencapaian yang akan membentuk loyalitas nasabahnya. Nasabah yang terpuaskan dapat menyebarluaskan pengalamannya kepada nasabah yang lain. Sebaliknya nasabah yang tidak terpuaskan maka dapat menjadi iklan yang buruk bagi perbankan karena dapat menghilangkan nasabah baru.

Loyalitas nasabah terlihat dari intensitas menabung nasabah yang lebih sering ketika melakukan setoran dengan menggunakan sistem setoran online Usid Gateway. Intensitas menabung tersebut muncul sebagai timbal balik yang diberikan nasabah terhadap kepuasan yang diperoleh.Hal tersebut sesuai dengan apa yang dikemukakan oleh Sunarto yang menyatakan bahwa loyalitas pelanggan atau customer loyalty merupakan suatu ukuran keterikatan pelanggan terhadap sebuah merek. Ukuran ini mampu memberikan gambaran tentang mungkin tidaknya pelanggan beralih ke merek produk yang lain, apabila merek produk tersebut didapati adanya perubahan, baik menyangkut harga maupun atribut lain. Loyalitas pelanggan tidak terbentuk dalam waktu yang singkat, tetapi melalui proses belajar dan berdasakan hasil pengalaman itu sendiri dari pembelian yang konsisten sepanjang waktu. ${ }^{16}$

\footnotetext{
${ }^{15}$ Ibid, hlm. 78

${ }^{16}$ Sunarto."Perilaku Konsumen”. Yogyakarta: AMUS. 2010. hlm 75
} 
Loyalitas nasabah sangat berpengaruh terhadap tabungan umum syariah melalui minat menabung nasabah dan kontribusi dana pihak ketiga yang dihasilkan. Kontribusi dana pihak ketiga yang dihasilkan oleh tabungan umum syariah kepada BMT UGT Sidogiri Cabang Klampis Kabupaten Bangkalan meningkat selama tiga tahun terakhir sejak sistem setoran online Usid Gateway diberlakukan yang hal tesebut juga berpengaruh terhadap kekuatan likuiditas perusahaan.

Layanan setoran online yang merupakan salah satu layanan yang difavoritkan oleh sebagian besar nasabah BMT UGT Sidogiri Cabang Klampis Kabupaten Bangkalan harus tetap dijaga konsistensi kualitas pelayanannya, agar loyalitas nasabah yang telah dibangun tetap terjaga. Kualitas pelayanan adalah sebuah kata yang bagi penyedia jasa merupakan sesuatu yang harus dikerjakan dengan baik. Ketika produk tidak berwujud tidak dapat dengan mudah dibedakan, kunci utama keberhasilan kompetitifnya terletak pada penambahan nilai jasa pelayanan yang baik dan peningkatan kualitas produk. ${ }^{17}$

Kualitas pelayanan merupakan faktor utama yang mempengaruhi loyalitas pelanggan dikarenakan pelanggan yang terpuaskan nilai pribadinya dan mengalami mood yang positif terhadap pelayanan akan memiliki loyalitas yang tinggi terhadap perusahaan tersebut. Pelanggan seringkali tidak loyal disebabkan oleh adanya pelayanan yang buruk atau kualitas pelayanan yang semakin menurun dari yang diharapkan pelanggan. Oleh karena itu KJKS BMT UGT Sidogiri Cabang Klampis Kabupaten Bangkalan dapat terus mengembangkan kualitas sistem pelayanan yang diberikan dan juga terus meningkatkan pelayanannya pada setiap bidang selain dalam bidang administrasi kepada nasabahnya.

BMT UGT Sidogiri yang merupakan lembaga keuangan syariah mikro sangat tepat jika berada di tengah tengah masyarakat yang tingkat kesejahteraannya mayoritas berada di tingkat menengah ke bawah. Akan tetapi jika tidak ditunjang dengan kemudahan dan pelayanan yang prima. BMT UGT Sidogiri akan ditinggalkan oleh nasabahnya.

${ }^{17}$ Supranto.“Pengukuran Tingkat Kepuasan Pelanggan Untuk Menaikkan Pangsa Pasar. Jakarta: Rineka Cipta. 2011, hlm 80 


\section{Simpulan}

Persepsi layanan setoran online di BMT UGT Sidogiri telah memenuhi kriteria layanan online dan berkualitas yang menurut sebagian besar nasabah baik dengan presentase 93,8 \%. Persepsi kepuasan nasabah terhadap layanan setoran online yang diberikan BMT UGT Sidogiri Cabang Klampis menurut sebagian besar nasabah cukup memuaskan dengan presentase 91,5\%. Persepsi loyalitas nasabah terhadap layanan setoran online yang diberikan BMT UGT Sidogiri Cabang Klampis menurut sebagian besar nasabah cukup memuaskan dengan presentase 93,1\%.

Adanya pengaruh yang signifikan antara layanan setoran online BMT UGT Sidogiri Cabang Klampis terhadap kepuasannasabah BMT UGT Sidogiri Cabang Klampis. Berdasarkan hasil korelasi $\mathrm{R}=0,841$ Dan $\mathrm{R}$ Square $=0,707$ dan $p$ value yang diperoleh $0,000<0,05$. Adanya pengaruh yang signifikan antara layanan setoran online BMT UGT Sidogiri Cabang Klampis terhadap kepuasan nasabah BMT UGT Sidogiri Cabang Klampis. Berdasarkan hasil korelasi $\mathrm{R}=0,849$ dan $\mathrm{R}$ Square $=0,721$ dan $\mathrm{p}$ value yang diperoleh $0,000<0,05$.

Mengingat strategi layanan setoran online merupakan keunggulan kompetitif yang dimiliki BMT UGT Sidogiri Cabang Klampis Kabupaten Bangkalan, maka penggunaanya harus benar-benar dimaksimalkan dengan menambah jumlah AO agar semua nasabah dapat menggunakan layanan ini secara maksimal. Kepuasan pelanggan yang menjadi target utama dalam produk sebuah jasa keuangan. Untuk mewujudkan kepuasan nasabah tersebut perlu ditingkatkan dengan total quality management terutama yang berkaitan dengan peningkatan pelayanan. Hal tersebut dapat diwujudkan dengan diadakannya pelatihan-pelatihan secara berkala, untuk meningkatkan kualitas sumber daya manusia dan teknologi yang dipalikasikan. 


\section{DAFTAR PUSTAKA}

Alma, Buchari. 2014. Manajemen Pemasaran dan Pemasaran Jasa. Bandung: Alfabeta.

Arikunto, Suharsimi. 2010. Prosedur Penelitian, Suatu Pendekatan Praktik. Jakarta: Rineka Cipta

Ainul Yaqin, Aniek Maschudah Ilfitriah. 2014. Pengaruh Kualitas Pelayanan Terhadap Kepuasan dan Loyalitas Nasabah Bank Pengguna E-Banking Di Surabaya. Journal of Business and Banking, Volume 4, No. 2, November 2014, pp 245 - 260.

Beerli a, dkk, "A Model of Customer Loyalty in the Retail Banking Market, European Journal of Marketing, Vol. 38, No. 1/2, 2004, pp. 253-275.

Daryanto, Isyanto, \& Setiabudi. Konsumen dan Pelayanan Prima. Jakarta: Raja Grafindo Persada

Fitri Apriliani, Srikandi Kumadji, Andriani Kusumawati. 2014. Pengaruh Relationship Marketing Terhadap Kepuasan dan Loyalitas Nasabah. Jurnal Administrasi Bisnis (JAB) Volume. 17 No. 1 Desember 2014. pp 178-185

Griffin, J. 2005. Customer Loyalty, Menumbuhkan dan Mempertahankan Kesetiaan Pelanggan. Jakarta: Erlangga

Hadi, Sutrisno. 2000. Metodelogi Research. Yogyakarta: Andi Offset

Irawan. 2010. 10 Prinsip Kepuasan Pelanggan. Jakarta: Gramedia Pustaka Utama.

Kasmir. 2012. Manajemen Perbankan. Jakarta: Raja Grafindo Persada.

Kharisma Nawang Sigit, Euis Soliha. 2017. Kualitas Produk dan Kualitas Layanan Terhadap Kepuasan dan Loyalitas Nasabah. Jurnal Keuangan dan Perbankan, Volume 2 No.1 Juli 2017 pp 157-168.

Kotler, Philip. Kevin Lane Keller. 2009. Manajemen Pemasaran. Edisi Ketiga Belas. Jakarta: Erlangga. 
Liza, Nor. 2016. Penggunaan Sistem Setoran Online UGT Sidogiri Gateway (Usid Gateway) dan Sistem Setoran Offline Studi Komparasi Terhadap Kepuasan Nasabah Pada Tabungan Umum Syariah di KJKS BMT Sidogiri Capem Mojo Surabaya. Skripsi. Surabaya: Program Studi Ekonomi Syariah Universitas Islam Negeri Sunan Ampel.

Mamang, Etta Sangadji, \& Sopiah. 2013. Perilaku Konsumen. Yogyakarta: Andi Offset.

Mohamad Fahmi, Tri Yuniati. 2013. Pengaruh Kepuasan dan Loyalitas Pelanggan Honda Terhadap Citra Perusahaan PT AHM. Jurnal Ilmu $\mathcal{E}$ Riset Manajemen Volume.2 No.1, 12 Mei 2013.pp 131-145

Muhammad Arifiean Isnan, Sutopo. 2014. Analisis Pengaruh Kualitas Pelayanan Online Reservation Ticket Terhadap Kepuasan Pelanggan. Jurnal Studi Manajemen \& Organisasi Volume 2 No.1, 11 Desember 2014 pp 143 - 152

Noor, Juliansyah. 2011. Metodologi Penelitian. Jakarta: Kencana Prenada Media Group.

PR.Smith. 2005. Great Answers To Tough Marketing Question Jawaban Jitu Untuk Berbagai Pertanyaan Pemasaran Yang Sulit. Jakarta: Intermedia

Rangkuti, Fredi 2006. Measuring Customer Satisfaction. Jakarta: Gramedia Pustaka Utama.

Riswandi, Ismail. 2014. Pengaruh Kualitas Layanan, Kualitas Produk Dan Kepuasan Nasabah Sebagai Prediktor Dalam Meningkatkan Loyalitas Nasabah. Jurnal Organisasi dan Manajemen, Volume 10, Nomor 2, September 2014. pp 179-196.

Sarwono, Jonathan. 2011. Buku Pintar IBM SPSS Statistics 19. Jakarta. Gramedia

Sugiyono. 2011. Metode Penelitian Kuantitatif, Kualitatif, dan RED. Bandung: Alfabeta.

Sulistyo, Joko. 2011. 6 Hari Jago SPSS. Yogyakarta: Cakrawala. 
Sunarto. 2010. Perilaku Konsumen. Yogyakarta: Penerbit AMUS.

Supranto, J. 2006. Pengukuran Tingkat Kepuasan Pelanggan: Untuk Menaikkan Pangsa Pasar. Jakarta: Rineka Cipta.

Tjiptono, Fandy \& Candra. 2005. Gregorius Service Quality \& Satisfaction. Yogyakarta: Andi Offset. 